\title{
Flipped Classroom Applied To High School with Whatsapp Aid
}

\author{
Ernane Rosa Martins \\ Federal Institute of Education \\ Science and Technology of Goiás (IFG) \\ Brazil \\ Luis Manuel Borges Gouveia \\ University of Fernando Pessoa (UFP)
}

\begin{abstract}
This work presents an experience report on the use of the Flipped Classroom (FC) methodology, with the assistance of WhatsApp as a tool for sharing content, in the support for learning in the discipline of web authoring of the technical course in computer science for the internet. The case study methodology was used to investigate students' behavior and reactions. It was verified through the reports of the students and observations that the experience with the FC and WhatsApp made it possible to learn and study at any time and place, allowed individualized monitoring by the teacher in the presential and virtual moments and improved the relationship between the student and the teacher.
\end{abstract}

Keywords: flipped classroom, WhatsApp, teaching.

\section{Introduction}

There are several concerns among educational researchers, one of which is how to integrate Information and Communication Technologies (ICT) into the pedagogical practice of teachers, in order to transform and update their performance in the classroom. Thus, we also have several methodologies that dynamize the teaching and learning process integrating the ICTs, among them one that stands out is the Flipped Classroom, known in Brazil as Inverted Classroom (IC), denomination that will be used in this research. According to its creators Jonathan Bergmann and Aaron Sams, in this methodology what was once done in the classroom of the traditional model, is now executed at home while the activities that were carried out alone by students as homework, are now performed in the classroom (Bergmann \& Sams, 2016). That is, the students study the content before going to the classroom, which becomes the place to work the contents previously studied, to carry out practical activities, to solve problems, to carry out projects, to group discussion and practical laboratories (Valente, 2014).

The IC approach can provide students with an environment conducive to collaborative learning. Bergmann \& Sams (2016) argue that in IC as the teacher can spend much of the time talking and answering questions of the students it is easier to individually guide the learning of each student. Thus, the teacher can also choose to have the students work in small groups, leaving the students less dependent on the teacher, and they can ask questions with each other. This concept of collaborative learning is related to learning and teaching in a group (Leite et al., 2005). Collaborative learning is directly related to shared learning (Jeong \& Hmelo-Silver, 2016).

With the advent of computer science and the internet, a profound transformation occurs in the communication processes of humanity, causing several educators to seek to integrate the resources offered by digital technologies and the teaching and learning process, allowing interaction and collaborative work, an area of study known as Computer Supported Collaborative Learning (CSCL) (Honor \& Scortegagna, 2017-b).

Therefore, this work presents an experience report about the use and evaluation of the IC methodology, with the assistance of WhatsApp as a tool for sharing content and communication, in support of learning. This study is justified because it was not found in the literature a study of the evaluation of the IC methodology combined with WhatsApp as a cognitive tool.

This article is structured in five sections. In this section we present, besides the introduction, the definition of the research problem, the objective, the justification and importance of the study and the structure of the present research. 
Section 2 brings the theoretical framework, with the formation of a conceptual and theoretical basis, which provide support for the development of this study. Section 3 presents the method used and the techniques and methodological procedures used. Section 4 describes the results obtained in the research and discussion. Finally, section 5 retakes the purpose of the article, how it was achieved and proposes suggestions for future research.

\section{Literature review}

In this section we have the formation of a conceptual and theoretical basis, which provide subsidies for the development of this study.

\subsection{Flipped Classroom}

In this section we present the IC approach, which is a teaching model in which technology is used to reverse the traditional role of class time, students are exposed to concepts outside the classroom, through observation and analysis of videos, and classroom time is used to assimilate these new knowledge, through strategies such as problem solving, discussion or debate, being fully dedicated to active learning experiences. Thus, the use of technologies is used to share doubts and curiosities, completely changing the organization of the classroom, passing the students to the central position, promoting greater dynamics in the classroom (Carvalho \& Ramos, 2015).

The IC is an approach that promotes a systematic change in the classroom by promoting a proactive stance in students, who study the theoretical underpinnings of content before class and in class, begin to practice it. Thus, there is a decentralization of the attention of the teacher to the student, increasing the student's involvement (Davies \& Dean, 2013).

Thus, the teacher now has more time to leverage students' learning through individualized learning. Their role is now to guide them, indicating the contents they must study, preparing practical activities to be carried out in person, and possible doubts. The IC establishes a structure that ensures that students receive a personalized education adapted to their needs, the time of the teacher in the classroom can be used for research, discussion, collaboration, critical thinking and individual student monitoring (Bergmann \& Sams, 2012 ; The IC presents a series of benefits for those involved in the teaching and learning process, students, teachers and parents. With regard to students, it replaces passive learning with active learning, presents improvements in assessments, increases student responsibility, students can work at their own pace of learning, promotes the development of communication skills, teamwork, and collaboration of ideas. The teacher in turn has the possibility to improve the interaction with their students, reflect and improve their lessons from the video recording lessons. And parents can get more involved and follow the education and learning process of their children (Honor \& Scortegagna, 2017-a).

\subsection{WhatsApp as a cognitive tool}

This section presents the WhatsApp tool and its use in the educational process, as an adequate tool to support the construction of student learning. "Cognitive tools are computer tools adapted or developed to function as intellectual partners of the student in order to stimulate and facilitate critical thinking and higher order learning" (Jonassen, 2007).

Computational technologies are instruments that enhance and enrich learning by virtue of its multiple facets, producing unimaginable perspectives and aiding pedagogical practices. When used properly, it allows teachers to make their classes more engaging, dynamic, creative and productive. Assisting the explanation and exploration of the contents taught and collaborating in the students' learning progress. Students need more and more information that is concise, convincing and close to reality, which is possible through the insertion of computational technologies as a teaching didactic tool (Neto et al., 2017).

The New Technologies of Information and Communication (NICT) are increasingly being used, especially the WhatsApp tool, for making conversations, unlimited message exchanges with text, music, photos and videos, as well as the possibility of creating groups, which enable a rapid exchange of information between several individuals simultaneously, making this tool a very important possibility of knowledge construction (Souza, 2015). 
There are several authors who have recently researched the use of WhatsApp in education, such as: Kaieski, Grings \& Fetter (2015), showed that the use of WhatsApp promoted a greater engagement, participation and collaboration of the students in the process of teaching and learning significant beyond of the physical limits of the classroom; Pereira, Pereira \& Alves (2015), affirm that WhatsApp goes far beyond being a simple distributor of content; Neri (2015) states that Whatsapp can be used as a multimedia tool to make classes more attractive and consequently to improve the relationship between student and teacher; Leite \& Silva (2015) present a characterization of the chat genre through the WhatsApp application, given their relevance and popularity among mobile users; Machado-Spence (2015), presents preliminary reflections on an interdisciplinary experience that used the WhatsApp Messenger application as a resource for exchanging and discussing ideas in a work on Bullying and Cyberbullying and Araújo \& Bottentuit Junior (2015), present WhatsApp as an application of pedagogical-pedagogical communication viable to the teaching of philosophy, since many students have cell phones that access this application, besides attracting the attention of the students because it is something innovative, as a teaching strategy.

WhatsApp, when used in an educational context, can be used in a variety of ways, such as: environment for discussing subjects, solving problems, clarifying doubts and taking courses, and presenting several advantages such as: increased motivation and interactivity, and improvement in student-teacher relations. It may also present some difficulties, such as: need for planning, attention to application distractions, possibility of not all students having mobile devices and inherent difficulties of high message flow (Bottentuit Junior; Albuquerque \& Coutinho, 2016). But even so, this application has shown that it provides the possibility for students to act actively within the learning process (Souza, 2015).

\section{Methodology}

In this section we present the methodology used, which was the case study, with the instruments: direct observation of interactions, teacher's diary and students' reflections and perceptions. The research was applied in the discipline of Web Authorization of the first year of a technical course in computer science for the Internet, in the first two months of the 2017 academic year, addressing the content of HTML, shared in the format of videos, audios, images, PDFs, slides and documents.

According to Yin (2003), the case studies describe a phenomenon or intervention in the context in which it occurs. The literature review allowed to gather information on the subject, establishing the formulation of the research question. In order to carry out the activities, the students accessed and made available the contents and materials online previously in a WhatsApp group, which was used as a learning tool and that after the end of the two-month period an electronic Google Docs questionnaire was applied.

At first there was an explanation for students to become aware of the IC approach and the use of the WhatsApp tool for communication and sharing of content. All students reported that they had smartphone and internet availability and that they would use them for research and study.

According to the guidelines described by Bergmann \& Sams (2016) and Munhoz (2015), the implementation of the IC methodology is composed of three moments: online moment, in this case, with WhatsApp support; face-toface in the classroom for practical exercises and questions; and at the end of each class a moment of evaluation of the face-to-face meeting, through WhatsApp records, record of classroom observations and questionnaire applied to students. And so it always resumes the cycle again.

Respondents totaled all 34 students enrolled in the course. The questionnaire was composed of the following questions: What is the impact of the strategies used in their learning? Has the strategy promoted autonomy and motivation? Report your thoughts and opinions on the strategy used? What are your suggestions for improving your strategy? Did you find the use of WhatsApp in productive pedagogical activities?

The objectives of this research are exploratory and descriptive. Exploratory because it allows a closer proximity between the researcher and the problem, allowing to improve ideas or the discovery of new intuitions, and descriptive because some features presented by the students in the IC methodology will be exposed with the help of the WhatsApp tool. The content analysis was applied to the data collected from the questions. Each response was read more than once, coded and a frequency table was created. The themes were identified and, finally, the harmonization of codes and themes was examined. Significant statements from participants were included as citations to illustrate. The answers were tabulated with the Excel software, and analyzed later. 


\section{Results and Discussions}

In this section the results obtained in the research are described, as shown in Table 1.

\section{Table 1 Results of the strategy used}

\begin{tabular}{|c|c|}
\hline Instruments & Results obtained \\
\hline Direct observation & $\begin{array}{l}\text { The students used WhatsApp as an aid tool when doubts arose; } \\
\text { The concepts were absorbed by the totality of the students, being impossible to } \\
\text { advance in the matter otherwise, since the concepts of HTML are fundamental for } \\
\text { understanding the next contents of the discipline; } \\
\text { The students participated actively, asking and answering questions from colleagues; } \\
\text { No deviations were observed with other matters that had nothing to do with class; }\end{array}$ \\
\hline $\begin{array}{l}\text { Students' perceptions about the } \\
\text { impact of strategies used in } \\
\text { their learning }\end{array}$ & $\begin{array}{l}\text { Sharing of experiences, knowledge and contents; } \\
\text { Flexibility of study times, and can be done anywhere and at any time; } \\
\text { Convenience of having content in various } \\
\text { formats such as videos, slides, audios, etc.; } \\
\text { Integration among classmates; }\end{array}$ \\
\hline $\begin{array}{llr}\text { Perceptions } & \text { of strategy in } \\
\text { promoting } & \text { autonomy and } \\
\text { motivation } & \end{array}$ & $\begin{array}{l}\text { Most confirmed that the strategy contributed to motivation; } \\
\text { The students perceived a difference in the motivation of the class in relation to other } \\
\text { previous modules of the discipline; } \\
\text { They considered the use of WhatsApp as one of the factors of this motivation; } \\
\text { They considered collaborative involvement as one of the main reasons for feeling } \\
\text { motivated; }\end{array}$ \\
\hline Evaluation records & $\begin{array}{l}\text { There were no negative scores below } 6.0 \text {; } \\
\text { Class average was } 8.1 \text { - Considered excellent comparing to other classes in this same } \\
\text { content; }\end{array}$ \\
\hline Student reflections on strategy & $\begin{array}{l}\text { I think a good thing, since, all the students have a cell phone, and the cell phone is a } \\
\text { computer and will be helping in our researches and etc.; } \\
\text { I find it very interesting, a new way of teaching; } \\
\text { I think it's a good idea, due to the greater interaction between student and teacher; } \\
\text { Incredible, I find an engaging didactics, which helps to assimilate the content; } \\
\text { It is a way to connect all students interactively; } \\
\text { Very interesting because it leaves the class more dynamic; } \\
\text { It is a different and didactic way of teaching; } \\
\text { The technology helps a lot in our income; } \\
\text { Easier learning and communication; } \\
\text { It mixes something that we like to do that is to use the cell phone with what we are } \\
\text { obliged to study; }\end{array}$ \\
\hline $\begin{array}{l}\text { Suggestions to improve the } \\
\text { strategy }\end{array}$ & $\begin{array}{l}\text { Determine a timetable for everyone to be online to facilitate instant debate among all } \\
\text { students; }\end{array}$ \\
\hline
\end{tabular}

Bergmann and Sams (2016) and Munhoz (2015) confirmed the sharing of knowledge among students, using simply what they understood, demonstrating a great independence of the teacher's aid, confirming Bergmann and Sams (2016) and Munhoz (2015), which affirm that the IC methodology allows the students to become more independent, giving the teacher more attention to the students and consequently to get their doubts about the studied content.

By observing and analyzing the data recorded in WhatsApp, it was possible to verify that the communication and the sharing of content among the students occurred in a satisfactory way, functioning as a discussion forum, interacting and contributing to the construction of knowledge.

Some students' cooperation with video posting or PDF with resolution of exercises in which other members had doubts and theoretical summaries of specific themes of the content was evidenced. The improvement in student performance when compared to the performance obtained in other classes in this same content confirms Munhoz (2015), who states that in the IC the learning results are superior to those of the traditional method of teaching.

Among the main advantages identified, we have, that the teacher can follow the interactions online; the speed in the visualizations of the questions, being able to be answered by both the teacher and the colleagues themselves; and especially confirmation of message visualization, confirming the study by Alencar et. al. (2015). 
Another important point was that WhatsApp improved the interaction between the students, and between the teacher and the students, enabling them to get to know them better. Among the possible limitations pointed out by students, the financial and technical problems, although the technology is very accessible, was not the case, but may exclude some students who do not have a smartphone, internet plan on their cell phone or internet in residence. Although not reported by students, another problem that may occur is that the student can disperse with other available content that has nothing to do with the study.

The responses revealed that $94.3 \%$ of the students found WhatsApp to be productive in pedagogical activities and only $5.7 \%$ that they did not, mainly due to the fact that they did not feel totally free to express their doubts through messages in a group of Whatsapp. Comparing this group's learning with that of the previous year in the same period, there was a 31\% increase in the overall average with the use of IC and WhatsApp, with the grade point average being 6.2 in the previous year to 8.1 in the year investigated. Although it is not possible to determine this as the only determinant of the average variation from one year to the next, other factors such as teacher exchange also need to be taken into account.

\section{Final Considerations}

In this section we return to the purpose of the article, how it was achieved and proposed some suggestions for future research. Thus, this work aimed to present an experience report on the use and evaluation of the IC methodology, with the assistance of WhatsApp as a tool for sharing content and communication, in the learning support. The strategy used, the IC teaching model and the WhatsApp as a cognitive tool, were shown to be relevant and according to the obtained results, successful. The strategy stimulated students' responsibility for their own learning and enhanced learner-centered learning by making the teacher a knowledge manager.

It became clear through direct observation in the classes that the concepts were absorbed by the totality of the students, since to advance in the matter of Web Authoring these should be well internalized with the contents of HTML. The strategy generated a favorable environment for the teaching-learning process, making the students more independent of the teacher. WhatsApp communication enabled a more autonomous learning, enabling greater interaction in content and material sharing, instant messaging, opportunity to upload files, discussions and receive instant notifications, discussion of doubts and understanding and reflection of the users. content. Many schools, especially public schools, may not always be supported by a virtual learning environment. You can use WhatsApp as a practical alternative that is available with your students, in conjunction with the IC methodology, which can be used in any teaching area. Furthermore, this methodological approach was well accepted by the students and asked to continue until the end of the school year. As suggestions for future research, new interventions may be made in other classes, courses, levels of education and disciplines in order to confirm and consolidate this study.

\section{References}

Araújo, P. C., Bottentuit Junior, J. B. (2015). The WhatsApp Communication Application as Strategy in Teaching Philosophy. Thematic (João Pessoa, Online), v. XI, p. 11-23.

Bergmann, J., Sams, A. (2012). Flip Your Classroom: Talk to Every Student in Every Class Every Day Publisher: Inte.

Bergmann, J., Sams, A. (2016). Inverted classroom - an active learning methodology. 1. ed., Rio de Janeiro.

Bottentuit Junior, J. B., Albuquerque, O. C. P., Coutinho, C. P. (2016). WhatsApp and its Applications in Education: A Systematic Review of Literature. EducaOnline Magazine. Vol.10, no. 2: mai / ago, p. 67-97.

Carvalho, R. J. O., Ramos, A. (2015). Flipped classroom - focus student learning using cognitive tools. In International Conference on ICT in Education, pages 369-381.

Davies, R., Dean, D. D. N. (2013). Flipping the classroom and instructional technology integration in a collegelevel information systems spreadsheet course. Educational Technology Research and Development, 61 (4): 563-580.

Honor, H. L. G., Scortegagna, L. (2017-a). Reversing the classroom: process for the implementation of the inverted classroom methodology with elements of collaboration in teaching mathematics. Journal of Education, Science and Mathematics, v. 7, p. 206-219. 
Honor, H. L. G., Scortegagna, L. (2017-b). Reversed classroom practice: implementation and evaluation in mathematics teaching. In: XXIII Informatics Workshop at School, 2017, Recife. Recife - PE: CBIE. v. 1. p. 31-40.

Jeong, H., Hmelo-Silver, C. (2016). Seven affordances of computer-supported collaborative learning: How to support collaborative learning? How can Technologies help? Educational Psychologist. v. 51, n. December, 247-265.

Jonassen, D. (2007). Computers, Cognitive Tools - Develop critical thinking in schools. Oporto: Porto Editora.

Kaieski, N., Grings, J. A., Fetter, S. A. (2015). A study on the pedagogical possibilities of using WhatsApp. RENOTE New Technologies Magazine in Education, v. 13, p. 1-10.

Leite, C. L. K., Passos, M. O. De A., Torres, P. L., Alcântara, P. R. (2005). Collaborative learning in distance education online. [s.n.]. ABED.

Leite, N. C., Silva, M. O. (2015). WhatsApp: characterization of the chat genre in the context of teaching foreign languages. Revista Texto Livre, v. 8, p. 85-97.

Machado-Spence, N. C. F. (2015). The WhatsApp Messenger as a Resource in Higher Education: Narrative of an Interdisciplinary Experience. Revista de Educação do Vale do Arinos - RELVA, v. 1, p. 1-14.

Munhoz, A. S. (2015). Let's reverse the classroom? .1. ed. Authors Club.

Neri, J. H. P. (2015). Social Media in Schools use WhatsApp as a pedagogical tool in high school. Scientific Station (Juiz de Fora, Printed), p. 1-25.

Neto, R. N. De A. S., Rezende, S. R., Nogueira, T. (2017). Use of Educational Software as a DidacticPedagogical Resource for Teaching Geography. V Regional School of Informatics of Goiás - ERI-GO, Goiânia - GO, P. 185-197.

Pereira, P. C., Pereira, R. S., Alves, J. Da C. (2015). Virtual Environments and Communication Media, addressing the media explosion in the information society and its impact on learning - the use of WhatsApp as a mlearning platform. Mosaic Magazine. Jan./Jun.; 06 (1): 29-41.

Souza, C. F. de. (2015). Non-distance learning: mobile digital technology in English language teaching. Revista Texto Livre, v. 8, p. 39-50.

Valente, J. A. (2014). Blended learning and changes in higher education: the proposal of the classroom reversed. Educar em Revista, v. Special Issue, n. 4, 79-97.

Yin, R. (2003). Case Study Research: Design and Methods (3rd Ed.). Thousand Oaks, CA: Sage. 